\title{
Ferrous (Ii) Sulphate (Feso4) Indicator Label As Spoiled Meat Detector
}

\author{
Endang Warsiki ${ }^{1 *}$ dan Aldyanza Yusuf Shyna Iskandar ${ }^{1}$ \\ ${ }^{1}$ Departemen Teknologi Industri Pertanian, Fakultas Teknologi Pertanian, Institut Pertanian Bogor \\ Kampus IPB Darmaga P.O Box 220, Bogor 16002 \\ *Email : endangwarsiki@apps.ipb.ac.id
}

\begin{abstract}
Smart packaging is the packaging that can monitor and provide the information about quality of the packed product. This study was aimed to produce a label with indicator ferri sulphate ( $\mathrm{FeSO}_{4}$ ) to detect $\mathrm{H}_{2} \mathrm{~S}$ produced by poultry and to study the color change of the label response to $\mathrm{H}_{2} \mathrm{~S}$ exposure. Preliminary study showed that the best label was obtained with the formula of 3 grams chitosan, $70 \mathrm{ml}$ acetic acid $1 \%, 30 \mathrm{ml}$ aquadest and 2,5 gram FeSO . It was also known that $\mathrm{H}_{2} \mathrm{~S}$ concentration increased during storage at room temperature, from $0 \mathrm{ppm}$ at the first hour to $18.3 \mathrm{ppm}$ at 120th hour. There were significant differences in the value of $L, a, b$ and ${ }^{\circ}$ hue at $\alpha=5 \%$. Lightness value decreased from 34.26 to 7.44 in the end of storage. Value of a changed positively to red color, from 17.17 to 32.45 and value of b turned negative from 51.67 to 10.26. Therefore, ' hue showed that at 0-24 hours indicator was in yellow-red zone, at 24-96 hours in red zone and at 120 hours in red-purple zone. Further, the study showed that meat stored in room temperature for 24 hours already spoiled. Microorganism was also detected to grow more during storage. The growth in the beginning was $7 \times 105$ cfu/gram and became $71.5 \times 105 \mathrm{cfu} / \mathrm{gram}$. Based on SNI, the limit for microorganisms is $10 \times 105 \mathrm{cfu} / \mathrm{gram}$. Ferri sulphate could be used as spoilage detector by changing the indicator color from yellow-red to dark brown.
\end{abstract}

Keywords: smart label, indicator, $\mathrm{H} 2 \mathrm{~S}, \mathrm{FeSO} 4$ 


\section{PENDAHULUAN}

Jaminan keamanan pangan adalah mutlak untuk produk pangan. Namun demikian jaminan ini belum seluruhnya didapatkan oleh konsumen karena masih adanya kerusakan produk yang sulit dilihat oleh para konsumen secara kasat mata. Produk dapat rusak selama masa penyimpanan, distribusi serta penjualannya walaupun masa kedaluarsa belum terlampaui. Kesulitan mengindentikasi kerusakan produk pangan tersebut disebabkan karena produk tersebut tidak memberikan perubahan nyata pada bentuk visual, melainkan terjadi reaksi yang menghasilkan gas maupun senyawa kimia lain. Berbagai bentuk kerusakan yang tidak kasat mata ini dapat disiasati dengan penggunaan kemasan cerdas bersensor.

Kemasan cerdas adalah kemasan yang mampu memantau kondisi makanan dalam kemasan dan memberikan informasi kualitas makanan kemasan tersebut selama proses transportasi dan penyimpanan (Ahvenainen et al. 2013). Label indicator merupakan sensor yang terdapat pada kemasan cerdas. Penelitian Warsiki et al. (2012) telah membuat label indikator warna dengan pewarna alami dan sintetis. Label tersebut sangat prospektif untuk mendeteksi penurunan mutu produk pangan yang ditunjukan dengan perubahan $\mathrm{pH}$ produk. Selain itu, Nofrida et al. (2013) juga membuat label indikator warna daun erpa yang dapat mendeteksi penurunan mutu karena paparan suhu tinggi.

Salah satu produk makanan sehari-hari yang dapat dikemas dengan menggunakan kemasan cerdas adalah daging ayam. Seperti yang sudah diketahui daging dan olahan daging sangat mudah rusak dan busuk. Frazier and Westhoff (1981) menyatakan bahwa pembusukan adalah dekomposisi protein oleh bakteri yang menghasilkan senyawa yang berbau busuk, seperti indol, skatol, merkaptan aminamin dan $\mathrm{H}_{2} \mathrm{~S}$ serta $\mathrm{NH}_{3}$. Kemasan cerdas dapat dibuat untuk mendeteksi senyawa hasil pembusukan daging tersebut. Lestari (2013) telah membuat label indikator pendeteksi Escherichia coli pada daging. Label tersebut dapat mendeteksi mutu daging selama penyimpanan.

Pada penelitian sebelumnya Kato et al. (2011) telah membuat indikator yang dapat mendeteksi gas $\mathrm{H} 2 \mathrm{~S}$ dengan menggunakan $\mathrm{FeSO}_{4}$. Indikator tersebut dapat mendeteksi gas $\mathrm{H}_{2} \mathrm{~S}$ sebesar 100 ppm atau lebih dengan menunjukkan perubahan warna $\mathrm{FeSO}_{4}$ menjadi kehitaman. Namun, pada proses pembusukan daging belum diketahui berapa banyak gas H2S yang terbentuk. Oleh karena itu perlu dilakukan pengujian jumlah $\mathrm{H}_{2} \mathrm{~S}$ yang terbentuk selama penyimpanan daging ayam serta pengaruhnya terhadap indikator gas $\mathrm{H} 2 \mathrm{~S}$ yang dibuat.

\section{METODE}

Tahapan yang dilakukan dalam penelitian ini adalah pembuatan label indikator dengan metode oles dan aplikasi label indikator.

\section{Pembuatan Label Indikator dengan Metode Oles}

Larutan indikator dibuat berdasarkan penelitian Kato et al. (2011) yang dimodifikasi. Penelitian pendahuluan menyebutkan bahwa kitosan berukuran 80 mesh sebanyak 3 gram dilarutkan dalam $70 \mathrm{ml}$ asam asetat glasial 1\% dan $30 \mathrm{ml}$ akuades. Homogenasi dilakukan dengan magnetic stirrer pada suhu $27^{\circ} \mathrm{C}$ selama 60 menit. Setelah itu ditambahkan $\mathrm{FeSO}_{4}$ sebanyak 2,5 gram dan diaduk kembali pada suhu tetap selama 45 menit. Larutan yang terbentuk kemudian dioleskan pada kertas glossy dengan teknik oles sedang.

\section{Aplikasi Label Indikator}

Label indikator berukuran $1 \mathrm{~cm} \times 1 \mathrm{~cm}$ diletakkan pada sisi dalam styrofoam. Kemudian sebanyak 50 gram daging diletakkan pada styrofoam dan ditutup dengan cling wrap film yang sebelumnya telah direkatkan label indikator (Gambar 1). Daging disimpan selama 120 jam pada suhu ruang. Uji dilakukan setiap 24 jam dan meliputi perubahan warna label, konsentrasi $\mathrm{H}_{2} \mathrm{~S}$ pada kemasan dan penurunan mutu daging yang terdiri dari kekerasan dan total plate count (TPC). 


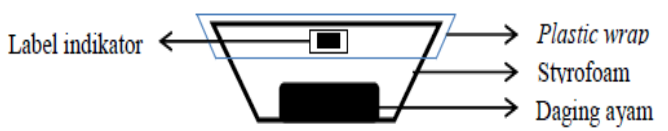

Gambar 1 Aplikasi label indikator pada pengemasan daging ayam

\section{Uji Perubahan Warna Indikator}

Respon perubahan warna indikator terhadap $\mathrm{H}_{2} \mathrm{~S}$ diuji setiap 24 jam dengan colorimeter. Label indikator dianalisis warna (Hunter 1958) dan diperoleh nilai L, a, b dan ${ }^{\circ}$ hue. Nilai ${ }^{\circ}$ hue kemudian dibandingkan terhadap tabel kisaran warna kromatis (Hutchings 1999).

\section{Uji Konsentrasi H2S}

Uji konsentrasi gas dilakukan dengan menggunakan gas analyzer. Kemasan hasil aplikasi penyimpanan dibuka sedikit untuk memasukan sensor gas analyzer. Hasil pengukuran akan tertera pada panel layar dan ditunggu hingga menunjukan nilai stabil.

\section{Uji Kekerasan Daging Ayam}

Daging ayam sebanyak 50 gram disimpan didalam wadah styrofoam dan ditutup dengan plastic wrap (Gambar 2). Sampel dibuat sebanyak enam buah, kemudian setiap 24 jam diuji dengan penetrometer hingga jam ke-120. Proses pengujian kekerasan dilakukan dengan tiga titik yakni bagian tengah, sudut atas dan bawah, nilai kekerasan adalah hasil rata-rata.

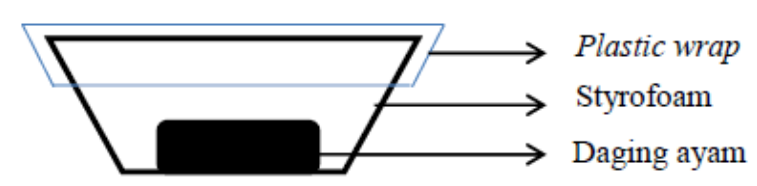

Gambar 2 Pengemasan daging ayam

\section{Uji Total Plate Count (TPC)}

Daging disimpan seperti Gambar 2 kemudian diuji TPC setiap 24 jam. Pengujian TPC dilakukan hingga pengenceran 10-5. Jumlah total mikroba dinyatakan dalam $\mathrm{cfu} / \mathrm{g}$.

\section{HASIL DAN PEMBAHASAN}

\section{Label Indikator dengan Teknik Oles}

Bahan utama yang digunakan dan berperan sebagai indikator utama $\mathrm{H}_{2} \mathrm{~S}$ adalah besi (II) sulfat $\left(\mathrm{FeSO}_{4}\right)$. Besi (II) sulfat atau ferri sulfat adalah senyawa kimia dengan rumus $\mathrm{FeSO}_{4}$ dan memiliki bentuk umum heptahidrat biru-hijau (USPDI 1989). Besi (II) sulfat dipilih karena dapat bereaksi dengan gas hidrogen sulfida yang muncul dari proses pembusukan daging. Salle (1961) menyebutkan bahwa gas $\mathrm{H}_{2} \mathrm{~S}$ terbentuk akibat terjadinya penguraian zat-zat organik oleh bakteri. Gas ini merupakan gas tidak berwarna, beracun dan sangat mudah terbakar (USEPA 2003). $\mathrm{FeSO}_{4}$ akan bereaksi dengan H2S menjadi $\mathrm{FeS}$ dan $\mathrm{H}_{2} \mathrm{SO}_{4}$ (Kato et al. 2011). FeS memiliki warna hitam sehingga seolah-olah terjadi perubahan warna $\mathrm{FeSO}_{4}$ dari yang sebelumnya berwarna kuning kemerahan.

Teknik oles dilakukan pada kertas glossy karena merupakan kertas dengan sifat mengkilap, putih dan mampu menghasil cetakan sesuai dengan standar (Wijarnoko 2010). Warna putih membuat warna indikator lebih kontras dan kertas glossy sangat baik untuk digunakan sebagai media merekatnya indikator. Kertas ini juga memiliki ketebalan $2 \mathrm{~mm}$ yang cukup untuk menahan media indikator agar tidak bermigrasi ke produk ketika digunakan pada aplikasi nyata.

Keuntungan dari teknik ini adalah indikator yang dibuat tidak rusak. Teknik oles dilakukan karena menurut Sumarto (2008) polimer yang berupa larutan encer memiliki rantai bebas bergerak sehingga kemungkinan terbentuk konfigurasi rantai yang beragam, sementara polimer yang berbentuk padat 
memiliki rantai tidak teratur sehingga gerakan dan konfigurasinya terbatas. Hal ini menjelaskan bahwa formulasi yang dioleskan pada kertas glossy memiliki warna dan bentuk yang stabil (Gambar 3).

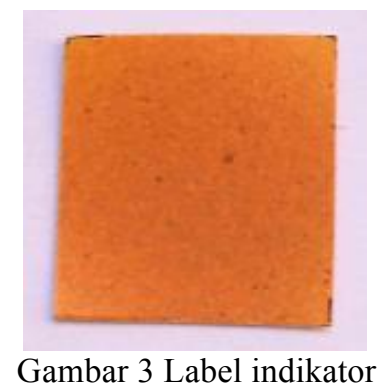

Label indikator yang dihasilkan memiliki warna tidak terlalu gelap ataupun tidak terlalu muda. Selain itu label indikator yang dihasilkan halus, tidak rapuh serta cukup jernih. Hasil pembuatan label indikator dipengaruhi oleh mutu kitosan yang digunakan. Kitosan yang tercampur dengan bahan pengotor akan menghasilkan indikator yang kasar. Selain itu, ukuran kitosan juga mempengaruhi label indikator yang dihasilkan. Masing-masing bahan memiliki ukuran minimum agar dapat larut dalam suatu pelarut. Dalam penelitian ini kitosan mudah larut dalam asam asetat pada ukuran 80 mesh.

\section{Aplikasi Label Indikator}

Label indikator E2 diaplikasikan pada daging ayam seperti yang terlihat pada Gambar 4. Pengemasan ini dibuat semirip mungkin dengan kemasan daging ayam ketika dijual di supermarket. Penyimpanan dilakukan pada suhu ruang agar proses pembusukan lebih cepat sehingga mudah diamati.

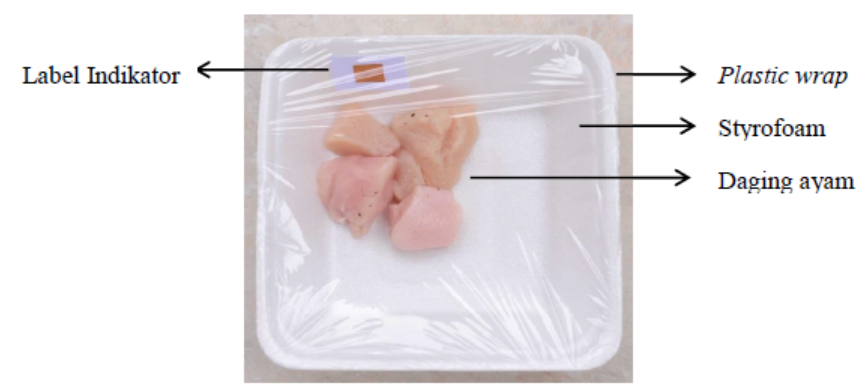

Gambar 4 Aplikasi indikator pada penyimpanan daging ayam

\section{Respon Warna Label Indikator Terhadap Konsentrasi Gas $\mathrm{H}_{2} \mathrm{~S}$}

Kebusukan daging dapat menyebabkan gas beraroma tidak sedap. Hal ini disebabkan bakteri yang mendekomposisi protein menjadi asam amino dan terdeaminasi menjadi senyawa berbau busuk. Beberapa organisme tersebut adalah Pseudomonas, Citrobacter, Aeromonas, Salmonella, dan Escherichia coli. Gas $\mathrm{H}_{2} \mathrm{~S}$ yang dihasilkan daging selama penyimpanan dapat dilihat pada Gambar 5. 


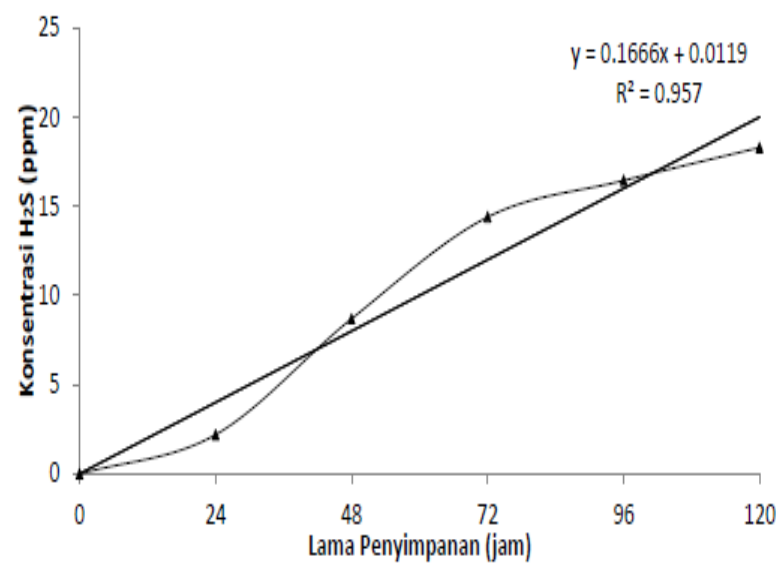

Gambar 5 Konsentrasi $\mathrm{H}_{2} \mathrm{~S}$ terhadap lama penyimpanan

Gas $\mathrm{H}_{2} \mathrm{~S}$ yang dihasilkan oleh daging akan ditangkap oleh $\mathrm{FeSO}_{4}$ yang terdapat pada indikator. $\mathrm{FeSO}_{4}$ merupakan indikator yang dapat digunakan untuk mendeteksi gas $\mathrm{H}_{2} \mathrm{~S}$ (Duncan 2005). Hasil perubahan nilai warna ditunjukan oleh Tabel 1. Terjadi perubahan warna indikator dari kuning menjadi lebih gelap disertai perubahan fisik daging ayam. Warna kuning pada indikator berubah menjadi gelap karena terpapar oleh gas $\mathrm{H}_{2} \mathrm{~S}$. Reaksi perubahan $\mathrm{FeSO}_{4}$ akibat paparan $\mathrm{H} 2 \mathrm{~S}$ adalah (Kato et al 2011):

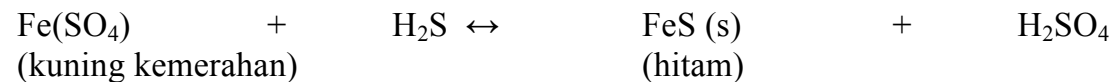

Warna pada FeSO4 berubah dari kuning menjadi hitam karena bakteri mampu mendesulfurasi asam amino menghasilkan gas $\mathrm{H} 2 \mathrm{~S}$ yang bereaksi dengan $\mathrm{Fe} 2+$ sehingga menghasilkan FeS berupa endapan warna hitam (Raihana 2011). Hasil pengamatan respon perubahan warna dapat dilihat pada Tabel 2.

Tabel 1 Nilai warna label indikator terhadap lama penyimpanan daging ayam

\begin{tabular}{ccccc}
\hline $\begin{array}{c}\text { Lama penyimpanan } \\
\text { daging ayam (jam) }\end{array}$ & Nilai L & Nilai a & Nilai b & Nilai ${ }^{\circ}$ hue \\
\hline 0 & 34,27 & 17,17 & 51,67 & 71,59 \\
24 & 21,98 & 17,76 & 35,49 & 63,30 \\
48 & 12,91 & 18,37 & 19,85 & 46,16 \\
72 & 8,80 & 21,65 & 12,70 & 29,59 \\
96 & 7,97 & 27,16 & 10,94 & 21,14 \\
120 & 7,44 & 32,45 & 10,26 & 17,81 \\
\hline
\end{tabular}

Tabel 2 Hasil pengamatan perubahan warna label indikator 


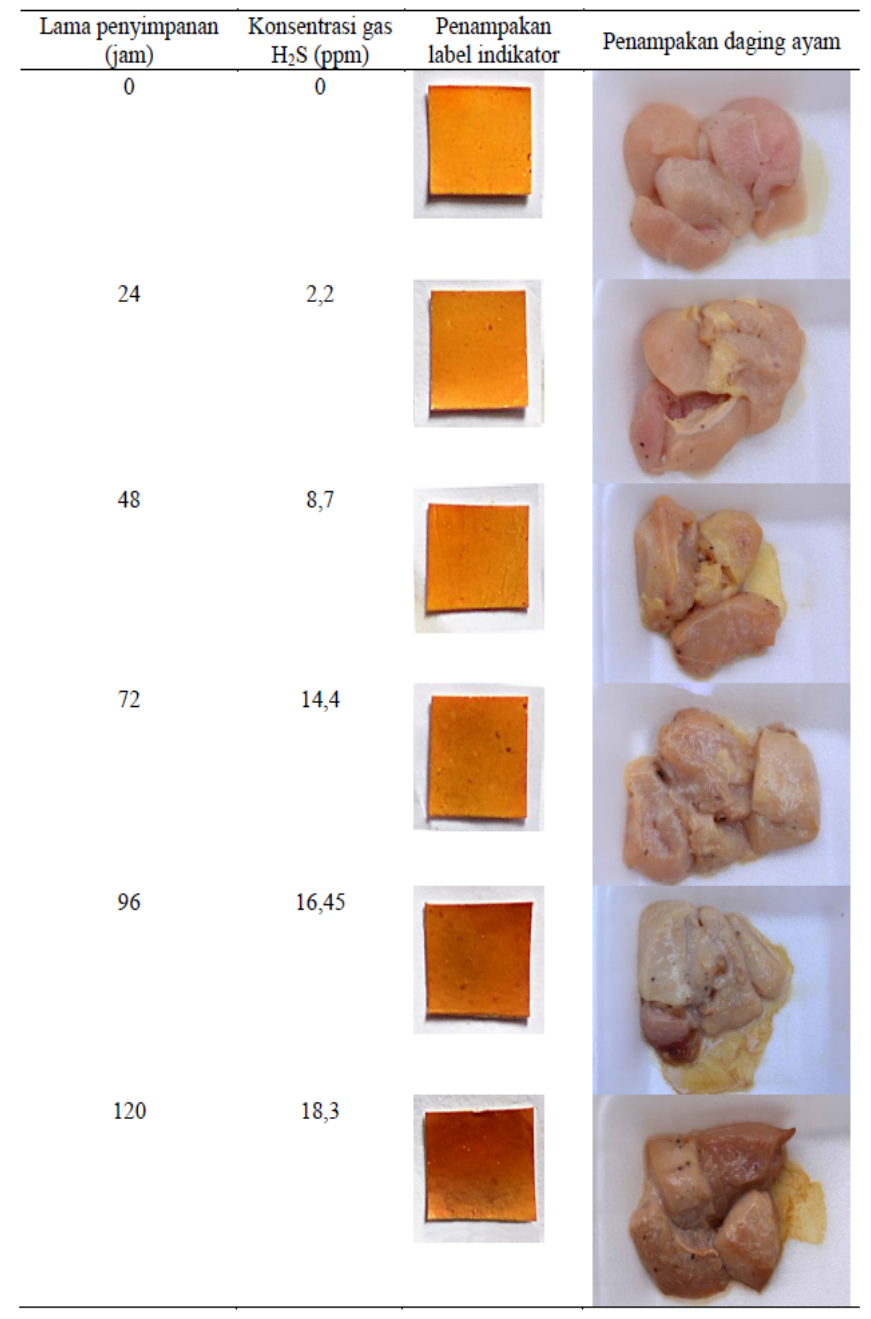

Dari Tabel 1 dapat diketahui respon perubahan warna label indikator selama penyimpanan daging ayam. Apabila nilai $\mathrm{L}$ pada tabel diatas dihubungkan dengan konsentrasi gas $\mathrm{H}_{2} \mathrm{~S}$ yang terproduksi seiring penyimpanan daging ayam, maka bisa diperoleh grafik seperti Gambar 6.

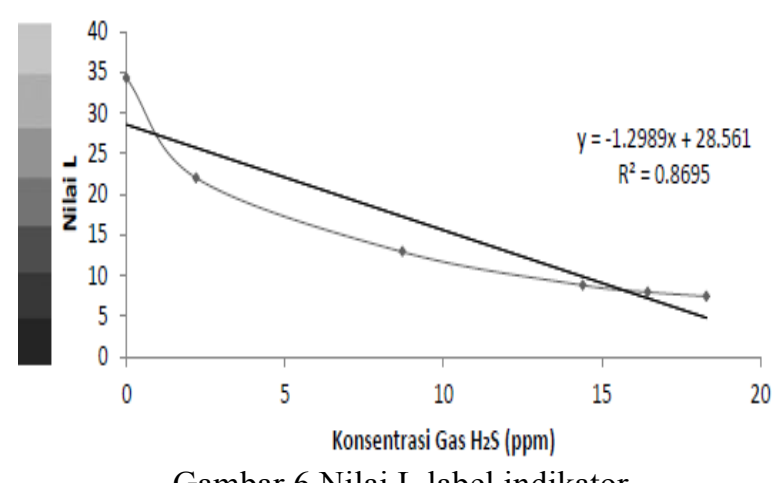

Gambar 6 Nilai L label indikator

Nilai L menunjukan tingkat kecerahan suatu sampel dengan interval nilai 0 (hitam) hingga 100 (putih). Semakin tinggi nilai L maka sampel memiliki warna yang semakin cerah (Nofrida 2013). Berdasarkan Gambar 6 dapat dilihat bahwa seiring dengan penambahan gas $\mathrm{H}_{2} \mathrm{~S}$ yang terbentuk, nilai $\mathrm{L}$ juga semakin menurun. Penurunan nilai L setiap penambahan gas $\mathrm{H} 2 \mathrm{~S}$ sebanyak $1 \mathrm{ppm}$ adalah sebesar 1,2989, ditunjukkan dengan nilai slope dari grafik tersebut. Nilai L mengalami penurunan karena gas $\mathrm{H}_{2} \mathrm{~S}$ yang terbentuk mengalami reaksi dengan $\mathrm{FeSO}_{4}$ pada label indikator sehingga berubah warna menjadi gelap. 
Selain itu, nilai yang terdeteksi lainnya dari pengujian warna adalah nilai a. Nilai a merupakan nilai yang menunjukan cahaya pantul sehingga menghasilkan warna kromatik campuran warna merah dan hijau. Nilai a positif $(+a)$ menunjukkan sampel memiliki derajat kemerahan, sedangkan nilai a negatif (-a) menunjukkan sampel memiliki derajat kehijauan (Nofrida 2013). Grafik perubahan nilai a dapat dilihat pada Gambar 7.

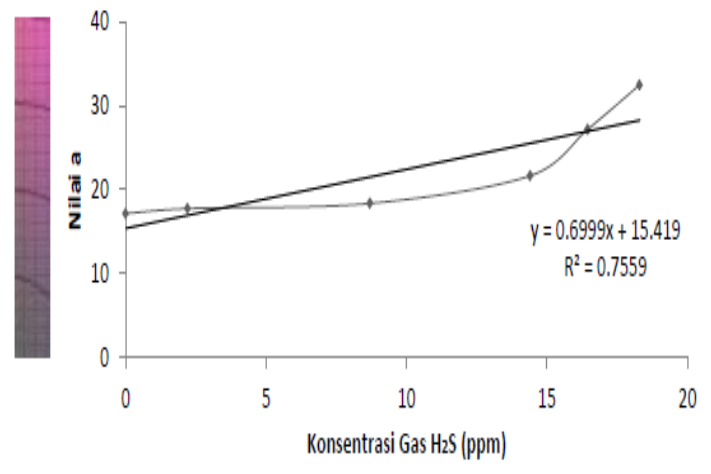

Gambar 7 Nilai a label indikator

Ketika konsentrasi H2S 0 ppm, nilai a yang ditunjukkan sebesar 17,17. Sementara ketika konsentrasi 18,3 ppm, nilai a sebesar 32,45. Semakin meningkat paparan $\mathrm{H}_{2} \mathrm{~S}$ akan semakin meingkat nilai a. Kecenderungan kenaikan nilai a dapat dilihat dari slope sebesar 0,6999 dari grafik tersebut.

Selain nilai a, pengukuran perubahan warna pada label indikator juga ditunjukkan dengan nilai b. Nilai $\mathrm{b}$ adalah nilai yang menunjukan derajat kekuningan dan kebiruan suatu sampel. Nilai b positif $(+\mathrm{b})$ menunjukan sampel memiliki derajat kekuningan, sedangkan nilai b negatif (-b) menunjukan sampel memiliki derajat kebiruan (Nofrida 2013). Grafik perubahan nilai b dapat dilihat pada Gambar 8.

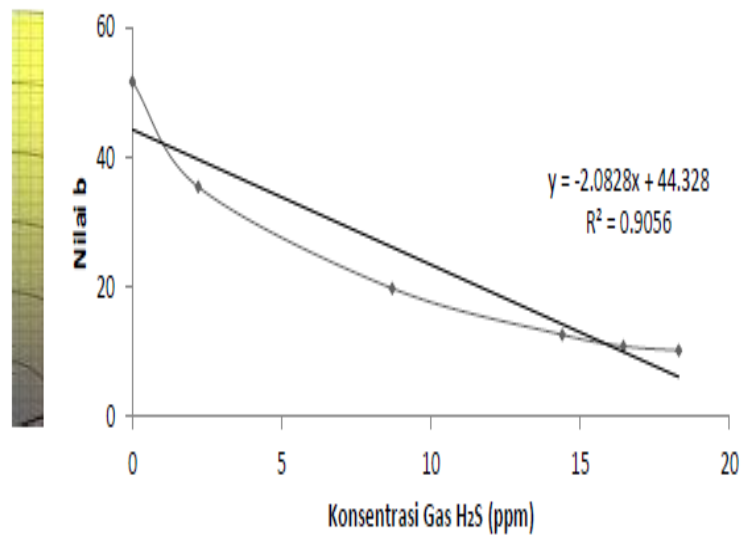

Gambar 8 Nilai b label indikator

Ketika $\mathrm{H}_{2} \mathrm{~S} 0$ ppm, nilai b ditunjukkan sebesar 51,67. Semakin tinggi konsentrasi $\mathrm{H} 2 \mathrm{~S}$ yang terbentuk maka nilai $\mathrm{b}$ akan turun. Hal tersebut terlihat ketika konsentrasi $\mathrm{H} 2 \mathrm{~S}$ sebesar $18,3 \mathrm{ppm}$ nilai $\mathrm{b}$ turun menjadi 10,26. Dari grafik dapat dilihat nilai slope yang sebesar -2,0828. Hal ini dikarenakan pergerakan nilai $b$ merupakan perubahan warna dasar dari indikator, yakni kuning, dan warna tersebut umumnya terlihat lebih jelas perubahannya.

Setelah mengetahui nilai a dan $b$, dapat ditentukan nilai ${ }^{\circ}$ hue. Nilai hue merupakan bagian dari pengujian yang menunjukan derajat warna yang dilihat indra penglihatan. Dalam sebuah skala warna yang seragam, perbedaan antara titik-titik plot dalam ruang warna dapat disamakan untuk melihat perbedaan warna yang direncanakan (Hunter 1958). Nilai hue dihitung dari invers tangen perbandingan nilai $\mathrm{b}$ dan nilai a (Lampiran 1). Nilai ${ }^{\circ}$ hue merupakan gambaran dari sumbu $360^{\circ}$ di mana daerah kuadran 1 menunjukkan warna kemerahan, daerah kuadran 2 menunjukkan warna kuning hijau, daerah kuadran 3 menunjukkan warna hijau biru, dan kuadran 4 menunjukkan warna ungu (MacDougall 2002). 
Dari nilai ${ }^{\circ}$ hue yang telah didapatkan terhadap lama penyimpanan, maka dapat diketahui warna kromatik visual yang terlihat apabila dihubungkan dengan jumlah gas $\mathrm{H}_{2} \mathrm{~S}$ yang terbentuk selama penyimpanan daging ayam. Grafik perubahan nilai ${ }^{\circ}$ hue dapat dilihat pada Gambar 9.

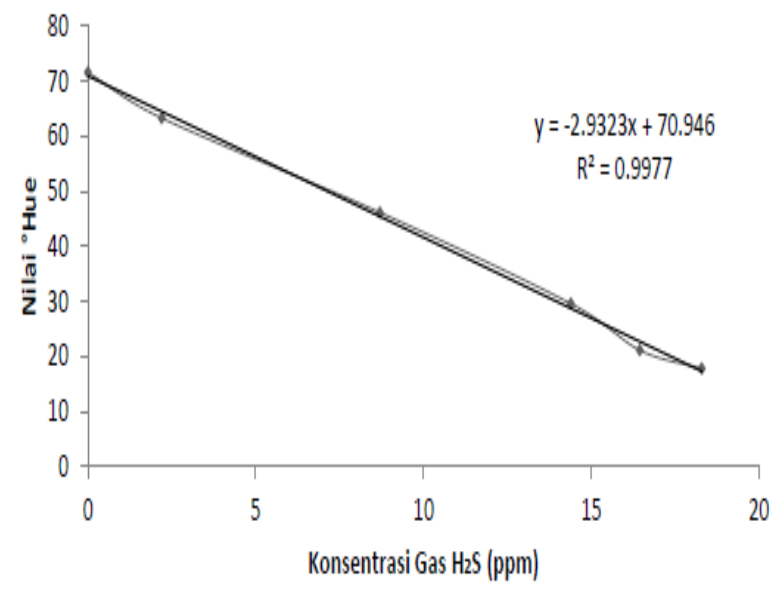

Gambar 9 Nilai ${ }^{\circ}$ hue label indikator

Pada saat konsentrasi H2S 0 ppm nilai ${ }^{\circ}$ hue sebesar 71,59. Hal ini menunjukkan bahwa warna kromatis indikator label pada mulanya adalah kuning-merah. Semakin tinggi konsentrasi gas $\mathrm{H}_{2} \mathrm{~S}$ maka ${ }^{\circ}$ hue semakin menurun. Hal ini dapat dilihat ketika konsentrasi $\mathrm{H}_{2} \mathrm{~S} 18,3 \mathrm{ppm}$, nilai ${ }^{\circ}$ hue turun menjadi $17,81^{\circ}$. Pada saat tersebut, warna kromatis indikator label berada pada kategori merah-ungu. Dari data tersebut dapat diperoleh nilai slope sebesar -2,9323, dimana terjadi penurunan pada grafik.

\section{Kekerasan Daging Ayam Selama Penyimpanan}

Uji kekerasan daging ditujukan untuk mengetahui kualitas dan kesegaran daging. Kekerasan daging banyak ditentukan oleh struktur miofibrial, status kontraksi, kandungan jaringan ikat dan tingkat ikatan silangnya, water holding capacity, dan jus daging. Selain itu, kekerasan daging juga bervariasi pada spesies dan otot yang sama (Soeparno 1992). Sehubungan dengan variasi tersebut, nilai kekerasan tidak tercantum sebagai salah satu parameter pada SNI daging ayam (BSN 2009). Hasil uji kekerasan dapat dilihat pada Gambar 10 .

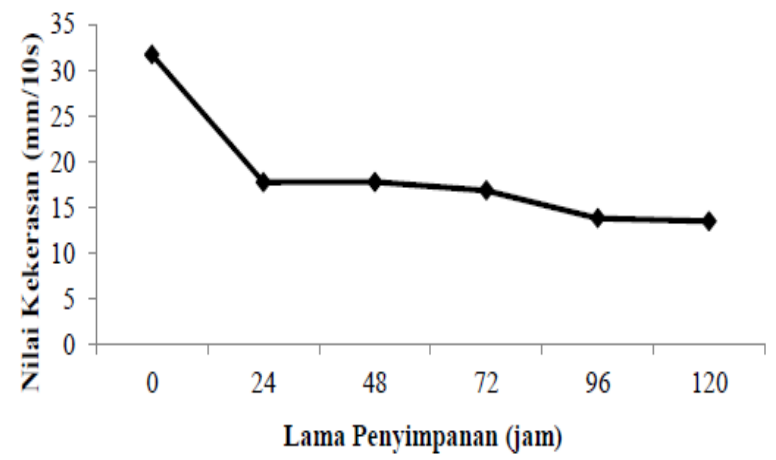

Gambar 10 Nilai kekerasan daging ayam terhadap lama penyimpanan

Hasil pengujian tersebut menunjukan pada jam ke-0 nilai kekerasan adalah $31,6 \mathrm{~mm} / 10 \mathrm{~s}$ dan semakin menurun hingga jam ke-120 menunjukan nilai 13,4 mm/10s. Hal tersebut menunjukkan bahwa semakin lama proses penyimpanan maka kekerasan daging semakin berkurang.

Nilai kekerasan merupakan nilai yang menunjukkan kedalaman jarum penetrometer dapat masuk ke dalam sampel selama 10 detik. Oleh karena itu, semakin dalam jarum, maka semakin tinggi nilai kekerasan yang dihasilkan. Hal tersebut menunjukkan bahwa nilai kekerasan berbanding terbalik dengan tingkat keempukan sampel. 
Hasil pengujian menunjukkan bahwa nilai kekerasan tertinggi diperoleh saat awal penyimpanan. Menurut Palupi (1986) sesaat setelah hewan dipotong, perubahan biokimia dalam jaringan masih terjadi. Setelah itu terjadi kerusakan yang disebabkan oleh mikroorganisme yang menempel pada daging. Mikroorganisme mendegradasi protein dan lemak menjadi gas, air dan senyawa kecil. Perubahan struktur tersebut mengakibatkan terurainya komponen daging dan perubahan tekstur menjadi lebih lunak. Hal ini sejalan dengan hasil pengamatan nilai TPC yang akan dibahas pada sub bab berikutnya. Namun air yang dihasilkan dari proses degradasi protein dan lemak akan menguap apabila daging tidak disimpan dalam suhu rendah. Hal tersebut membuat tekstur daging menjadi keras kembali.

Menurut Nareswari (2006), daging ayam yang baik akan memiliki tingkat kelunakan yang tinggi. Daging ayam yang mempunyai tingkat kelunakan rendah, apalagi diikuti dengan perubahan warna yang tidak normal menjadi tidak layak untuk dikonsumsi. Hal ini ditunjukkan oleh daging ayam yang disimpan selama 24 jam. Penurunan kelunakan secara signifikan mengakibatkan daging sudah tidak layak untuk dikonsumsi.

\section{Total Plate Count (TPC) Daging Ayam Selama Penyimpanan}

Proses pembusukan pada daging salah satunya disebabkan oleh mikroba. Menurut Sunarlim (1983) proses enzimatik yang berlangsung terus menerus pada daging (post mortem) akan mengundang mikroorganisme yang mengakibatkan pembusukan pada daging. Daging ayam mudah mengalami penurunan kualitas, salah satunya, sebagai akibat dari pertumbuhan dan aktifitas mikroorganisme dalam jumlah banyak selama penyimpanan (Sams 2001). Analisis mikrobiologis dapat dilakukan dengan analisis Total Plate Count (TPC). Hasil pengujian TPC pada daging ayam dalam penelitian ini dapat dilihat pada Gambar 11.

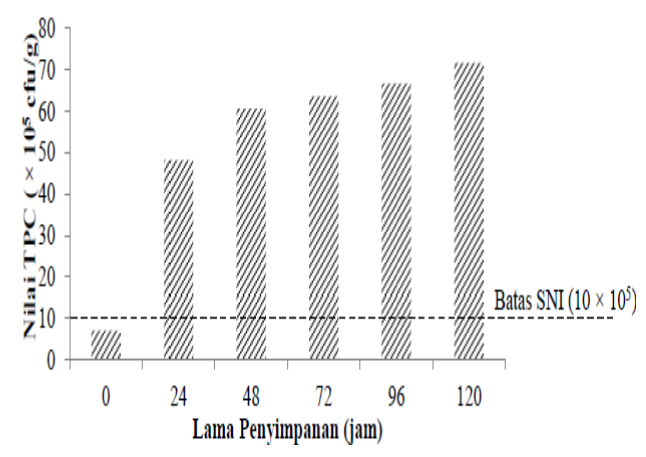

Gambar 11 Hasil uji total plate count (TPC) terhadap lama penyimpanan daging

Hasil pengujian menunjukan bahwa peningkatan nilai TPC terjadi dari jam ke-0 hingga jam ke-120. Pada awal penyimpanan, jumlah mikroba yang terdeteksi sebesar $7 \times 105 \mathrm{cfu} / \mathrm{g}$. Sementara itu peningkatan mikroba terus terdeteksi hingga pada penyimpanan daging ayam jam ke-120 diperoleh 71 $\times 105 \mathrm{cfu} / \mathrm{g}$. Berdasarkan hal ini dapat disimpulkan bahwa semakin lama waktu penyimpanan daging, maka semakin banyak mikroba yang tumbuh. Hal tersebut disebabkan karkas ayam merupakan media yang baik untuk perkembangan bakteri (Frazier dan Westhoff 1981). Brown (1982) juga menjelaskan bahwa aktivitas dan pertumbuhan bakteri menjadi salah satu faktor terjadinya pembusukan pada daging.

Anggraeni (2012) menyebutkan bahwa pengukuran seberapa jauh tingkat kerusakan daging dapat dilihat dari banyaknya bakteri yang tumbuh dan berkembang pada daging. Dalam penelitian ini, pengujian TPC daging ayam telah melewati ambang batas SNI untuk daging yang layak dikonsumsi pada lama penyimpanan 24 jam. Hal ini sesuai dengan penelitian Sukarya (2009) bahwa daging ayam mengalami kebusukan setelah penyimpanan 12 jam pada temperatur ruang. Penelitian Jay (1978) menjelaskan bahwa genus yang mendominasi pembusukan daging adalah Pseudomonas, Flavobacterium, Micrococcus, Bacillus, Streptococcus, Lactobacillus. Ditambahkan oleh Jensen (1987) bahwa daging ayam normal disimpan pada suhu kamar dengan penanganan kurang baik ditemukan mikroorganisme kelompok psikotrofik dan mesofilik. Mikroorganisme kelompok tersebutlah yang diduga mendominasi pada pengujian TPC ini. 
Dari hasil pengujian kekerasan dan TPC diketahui bahwa daging sudah tidak layak dikonsumsi setelah disimpan selama 24 jam. Sementara itu, perubahan tingkatan mutu daging selama penyimpanan dapat dilihat dari perubahan warna yang tampak secara visual. Pada tabel 5 diketahui bahwa daging ayam di awal penyimpanan bebas dari memar sehingga masuk pada tingkatan mutu I. Pada daging yang disimpan antara 24-120 jam daging sudah masuk dalam kategori rusak. Hal ini disebabkan muncul lendir serta terjadi perubahan warna menjadi lebih gelap pada daging yang disimpan lebih dari 24 jam. Munculnya lendir disebabkan oleh pertumbuhan mikroba yang melebihi batas SNI. Selain itu bau busuk juga muncul pada daging tersebut. Menurut Frazier dan Westhoff (1978), munculnya lendir, bau busuk dan perubahan warna pada daging ayam merupakan tanda-tanda pembusukan pada keadaan aerobik.

\section{Potensi Aplikasi Label Indikator}

Label indikator dapat digunakan sebagai pendeteksi gas $\mathrm{H}_{2} \mathrm{~S}$ pada kebusukan daging. Hal ini ditandai dengan terjadinya perubahan warna pada label indikator. Dari penampakan indikator secara visual terlihat degradasi warna seiring dengan peningkatan konsentrasi gas $\mathrm{H}_{2} \mathrm{~S}$ (Gambar 12).

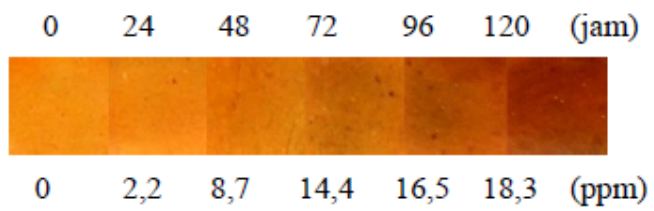

Gambar 12 Degradasi perubahan warna indikator terhadap konsentrasi gas H2S

Dari gradasi warna dapat dilihat terjadi perubahan warna yang dapat dilihat secara visual. Perubahan warna terjadi dari jingga menjadi lebih gelap. Hal ini berarti gas $\mathrm{H}_{2} \mathrm{~S}$ yang terdapat pada daging dapat bereaksi dengan indikator sehingga terjadi perubahan warna. Namun perubahan warna ini masih belum sensitif untuk mendeteksi kebusukan daging. Pada jam ke-24 daging sudah tidak layak untuk dikonsumsi dilihat dari nilai kekerasan yang turun drastis dan pertumbuhan mikroba yang tinggi, sedangkan label indikator baru memberikan perubahan yang signifikan pada jam ke-72. Oleh karena itu label indikator ini belum dapat digunakan sebagai penentu mutu daging.

\section{SIMPULAN DAN SARAN}

\section{Simpulan}

Label indikator gas $\mathrm{H}_{2} \mathrm{~S}$ dibuat dengan menggunakan kitosan dan $\mathrm{FeSO}_{4}$. Teknik pembuatan indikator menggunakan cara oles sedang. Formula terbaik yang digunakan adalah campuran kitosan sebanyak 3 gram, asam asetat glasial $1 \% 70 \mathrm{ml}$, akuades $30 \mathrm{ml}$ dan $\mathrm{FeSO}_{4}$ sebanyak 2,5 gram.

Warna indikator berupa nilai L, a dan $\mathrm{b}$ dan ${ }^{\circ}$ hue dipengaruhi secara signifikan oleh perbedaan lama penyimpanan daging ayam. Tingkat kecerahan warna indikator bergerak ke arah lebih gelap dari 34,265 di jam ke-0 menjadi 7,44 di jam ke-120. Nilai a bergerak secara positif ke warna merah dari 17,17 pada jam ke-0 hingga 32,45 di jam ke-120. Adapun nilai b juga bergerak ke arah negatif menuju warna biru dari 51,67 pada jam ke-0 menjadi 10,26 pada jam ke-120. Nilai ${ }^{\circ}$ hue pada jam ke-0 hingga jam ke-24 menunjukkan kategori warna kromatis kuning-merah, pada jam selanjutnya hingga jam ke96 indikator menunjukkan kategori warna kromatis merah dan pada jam ke-120 menunjukkan kategori merah-ungu.

Daging yang disimpan selama 120 jam mengalami peningkatan kekerasan dari 31,6 mm/10s di jam ke0 menjadi 13,4 mm/10s di jam ke-120. Selain itu daging juga mengalami peningkatan jumlah mikroba selama penyimpanan. Mikroba terdapat pada daging di jam ke-0 sebanyak $7 \times 105 \mathrm{cfu} / \mathrm{g}$ meningkat menjadi $71,5 \times 105 \mathrm{cfu} / \mathrm{g}$ pada jam ke-120. Mikroba yang terdapat pada daging menjadi salah satu 
penyebab munculnya gas $\mathrm{H}_{2} \mathrm{~S}$. Jumlah gas $\mathrm{H}_{2} \mathrm{~S}$ semakin meningkat seiring dengan lamanya penyimpanan, yakni dari 0 ppm menjadi $18,3 \mathrm{ppm}$.

Berdasarkan hasil penelitian, warna label indikator dapat berubah sesuai konsentrasi gas $\mathrm{H}_{2} \mathrm{~S}$ pada kemasan. Namun perubahan warna label indikator tidak secepat perubahan mutu daging sehingga label indikator $\mathrm{H}_{2} \mathrm{~S}$ ini belum dapat digunakan untuk mendeteksi kebusukan daging ayam.

\section{Saran}

Disarankan untuk formulasi label indikator agar dapat menunjukkan perubahan warna lebih sensitif terhadap tingkat kebusukan daging. Diperlukan agen pendeteksi lain seperti myoglobin.

\section{DAFTAR PUSTAKA}

Anggraeni E. 2012. Penggunaan Kitosan Sebagai Pengawet Alami Terhadap Mutu Daging Ayam Segar Selama Penyimpanan Suhu Ruang [Skripsi]. Bogor (ID): Institut Pertanian Bogor.

Ahvenainen R. 2003. Active and intelligent packaging. Di Dalam : Ahvenainen, R (ed). Novel Food Packaging Techniques. Abington: Woodhead Publishing, hlm 5-21

Badan Standardisasi Nasional. 2009. SNI 3924:2009 Daging Ayam. Jakarta (ID): Bada Standardisasi Nasional.

Beauchamp RO, Bus JS, Popp JA, Boreiko CJ, Andjelkovich DA, and Leber P. 1984. “A critical review of the literature on hydrogen sulfide toxicity." Critical Reviews in Toxicology 13 (1): 25-97.

Brown MH. 1982. Meat Microbiology. London: Applied Science Publishers.

Duncan F. 2005. MCB 1000L Applied Microbiology Laboratory Manual 4th Ed. New York (US): The McGraw-Hill Companies.

Frazier WC and Westhoff DC. 1981. Food Microbiology, 3 Ed. New Delhi: Mc. Graw Hill Pub. Co. Ltd.

Hunter RS. 1958. Photoelectric colour difference meter. J. of the optical Society of America 48 : 985 995 Di dalam : MacDouggall DB. 2002. Colour in Food : Improving Quality. Washington (US): CRC Press.

Hutching JB. 1999. Food Color and Appearance. Second Edition. Maruland (US): Chapman Hall Food Sci.

Jay JM. 1978. Modern Food Microbiology. Second Edition. New York (US): Van Nostrand Reinhold Company.

Jensen L. 1987. Microbiology of Meats. Third Edition. Illnois (US): The Garrard Press Publishers.

Kato ET, Yoshida CMP, Reis AB, Melo IS and Franco TT. 2011. Fast Detection of Hydrogen Sulfide Using A Biodegradable Colorimetric Indicator System. Polymer International Journal 60: 951-956.

Lestari IA. 2013. Pembuatan Label Cerdas Pendeteksi Escherichia Coli [Skripsi]. Bogor (ID): Insstitut Pertanian Bogor.

MacDougall. 2002. Colour in Food: Improving quality. Washington (US): CRC Press. 
Nofrida R. 2013. Film Indikator Warna Daun Erpa (Aerva sanguinolenta) sebagai Kemasan Cerdas untuk Produk Rentan Suhu dan Cahaya [Tesis]. Bogor (ID): Institut Pertanian Bogor.

Nofrida R, Warsiki E dan Yuliasih I. 2013. Pengaruh Suhu Penyimpanan Terhadap Perubahan warna Label Indikator Daun Erpa (Aerva sanguinolenta). Jurnal Teknologi Industri Petanian 23 (3): 232-241.

Nareswari AR. 2006. Identifikasi dan Karakterisasi Ayam Tiren [Skripsi]. Bogor (ID): Institut Pertanian Bogor.

Palupi WOE. 1986. Tinjauan Literatur Pengolahan Daging. Jakarta (ID): Pusat Dokumentasi Ilmiah Nasional. Lembaga Ilmu Pengetahuan Indonesia.

Putri CDW. 2012. Kemasan Cerdas Indikator Warna Untuk Mendeteksi Kesegaran Buah Nanas Potong Selama Penyimpanan [Skripsi]. Bogor (ID): Institut Pertanian Bogor.

Raihana N. 2011. Profil Kultur dan Uji Sensitivitas Bakteri Aerob dari Infeksi Luka Operasi Laparatomi di Bangsal Bedah RSUP Dr. M. Djamil Padang [Artikel]. Padang (ID): Universitas Andalas Padang.

Salle AJ. 1961. Fundamental Principles of Bacteriology. Ed ke-5. New York: McGraw-Hill.

Sams AR. 2001. Poultry Meat Processing. Washington DC: CRC Press.

Sukarya R. 2009. Aplikasi Bakteriosin dari Lactobacillis sp. Galur SCG 1223 Sebagai Pengawet Daging Ayam Segar [Skripsi]. Bogor (ID): Institut Pertanian Bogor.

Sumarto. 2008. Mempelajari Pengaruh Penambahan Asam Lemak dan Natrium Benzoat Terhadap Sifat Fisik, Mekanik, dan Aktivitas Antimikroba Film Edibel Kitosan [Skripsi]. Bogor (ID): Institut Pertanian Bogor.

Sunarlim R. 1983. Penggunaan Chlor Untuk Memperpanjang Daya Simpan Karkas [Tesis]. Bogor (ID): Institut Pertanian Bogor.

Soeparno. 1992. Ilmu dan Teknologi Daging. Yogyakarta (ID): Gadjah Mada University Press.

USEPA. 2003. Integrated Risk Information System Toxicity Summary for Hydrogen Sulfide. USA: USEPA. 